\title{
MIR1290 wt Allele
}

National Cancer Institute

\section{Source}

National Cancer Institute. MIR1290 wt Allele. NCI Thesaurus. Code C157556.

Human MIR1290 wild-type allele is located in the vicinity of 1 p36.13 and is 78 bases in length. This allele, which encodes MIR1290 pre-miRNA, may be involved in tumor cell invasion. 